\title{
Pengaruh Aflatoksin 9,58 ppb dalam Pakan Terhadap Biometrik Saluran Cerna dan Berat Badan Ayam Petelur Periode Awal Pertumbuhan
}

\section{Effect of Aflatoxin 9.58 ppb in Feed on Layer Gastrointestinal Biometrics and Body Weight at Initial Growth Period}

Dio Putra Pratama ${ }^{1}$, Benjamin Chr. Tehupuring ${ }^{2}$, Emmanuel Djoko Poetranto ${ }^{3}$, Hana Eliyani2 ${ }^{2}$, Soeharsono ${ }^{2}$, Wiwiek Tyasningsih ${ }^{3}$, Gracia Angelina Hendarti2 ${ }^{2}$ ${ }_{1}$ Student, ${ }^{2}$ Department of Veterinary Anatomy, ${ }^{3}$ Department of Veterinary Microbiology, Faculty of Veterinary Medicine, Universitas Airlangga Corresponding author: dio.putra.pratama-2015@fkh.unair.ac.id

\section{ABSTRACT}

The purpose of this study was to determine the effect of aflatoxin content of 9.58 $\mathrm{ppb}$ in feed on gastrointestinal biometrics and weight gain of laying hens in the early growth period. Thirty-six day old chicks (DOC) were used in this study and were divided into two groups P0 and P1. P0 (control group) was fed with 100\% basal diet and P1 (treatment group) was fed a diet with a composition of $80 \%$ basal feed $+20 \%$ aflatoxincontaining feed. After the DOC was adapted, the first feeding containing aflatoxin was given from the 20th day to the 60th day. Data collection was carried out three times, namely the 20th, 40th, and 60th days. At the end of each period, the chickens would be euthanized to collect data on the weight and length of the digestive tract and body weight. Weight gain with time increased, but had no significant effect $(p>0.05)$ between the control and treatment groups. Body weight continues to increase because the body's homeresis function is still running well. Observations on gastrointestinal biometrics showed significant differences $(\mathrm{p}<0.05)$ in oesophagus weight, proventriculus weight, ventriculus weight, jejunum weight, ileum weight and length, and cecum weight because aflatoxins have a direct effect on the digestive tract they pass. The conclusion of this study was that the provision of $20 \%$ aflatoxin-containing feed did not affect weight gain but had shown an effect on the biometrics of several gastrointestinal tracts.

Keywords: Aflatoxins, gastrointestinal biometrics, weight gain, laying hens

Received: 08-09-2020 Revised: 09-10-2020

Accepted: $10-11-2020$

\section{PENDAHULUAN}

Ayam petelur menjadi andalan sebagai ternak produksi yang tidak dapat diragukan lagi potensinya. Periode pertumbuhan sebagai masa persiapan sekaligus penentu produktivitas optimal diperlukan strategi yang tepat untuk mencapai puncak produksi. Sejumlah faktor patut diperhatikan untuk mengoptimalkan produktivitas. Faktor tersebut diantaranya yaitu pemilihan bibit yang unggul, kualitas pakan yang bermutu, serta manajemen pemeliharaan yang baik. Pakan yang tepat, berimbang, dan efisien, serta sesuai kebutuhan tentunya berpengaruh terhadap pertumbuhan, konsumsi pakan, pertambahan bobot badan, dan angka konversi pakan, serta kesehatan ayam petelur (Walukow, dkk., 2017). Periode awal pertumbuhan ayam petelur disebut juga periode kritis ayam petelur karena kualitas pakan mempengaruhi kualitas produksi yang dihasilkan (Unutio, dkk. 2016).

Berkaitan dengan kualitas pakan, masalah yang terjadi dilapangan adalah resiko pakan yang terkontaminasi oleh 
aflatoksin. Valchev, et al. (2017) menyatakan bahwa pakan unggas yang terkontaminasi oleh aflatoksin merupakan permasalahan dunia yang menyebabkan terjadinya kerugian di dalam industri perunggasan. Aflatoksin (AF) merupakan hasil produk metabolit sekunder dari jamur jenis Aspergillus parasiticus, Aspergillus nomius, dan Aspergillus flavus yang mencemari komoditas pertanian saat sebelum atau sesudah panen (Reddy, et al., 2010).

Di Indonesia pertumbuhan jamurjamur penghasil aflatoksin sangat tinggi disebabkan iklim Indonesia memungkinkan kontaminasi pakan aflatoksin tidak terhindari. Keadaan ini didasarkan atas pendapat Liu (2002) menyatakan bahwa di negara-negara Asia Tenggara sekitar 50\% jagung dan 90\% pakan unggas terkontaminasi mikotoksin yang meliputi aflatoksin, fumonisin, dan ochratoksin. Hal ini karena kelembaban dan suhu merupakan faktor utama yang mengendalikan produksi mikotoksin tersebut (Singh dan Mandal, 2014).

Berdasarkan penelitian yang dilakukan oleh Puspitasari (2018) menyatakan bahwa kasus pakan mengandung aflatoksin di Kabupaten Blitar Jawa Timur cukup tinggi, pada 20 peternakan di Blitar positif mengandung aflatoksin dengan kadar terendah sebesar 5,49 ppb dan kadar tertinggi sebesar 176,54 ppb. Kandungan aflatoksin dalam pakan dengan kadar rendah antara 15-30 ppb sudah mampu memberikan efek toksik bahkan dengan kadar dibawah itu karena sifat aflatoksin yang terakumulasi didalam tubuh (Rawal, et al., 2010). Aflatoksin menyebabkan hepatotoksik, karsinogenik, immunosupresif, menghambat pertumbuhan, penurunan berat badan, penurunan pertumbuhan sel-sel darah merah dan kandungannya (Maryam, dkk., 2003).
Semua spesies hewan peka terhadap aflatoksin diantaranya ayam, itik, puyuh, sapi, kambing, dan babi (Wijayanti, 2010). Data pengaruh aflatoksin terhadap broiler, itik, puyuh, sapi, dan babi sudah banyak dilaporkan, namun penelitian tentang efek aflatoksin terhadap ayam petelur masih sedikit dan jarang terutama terhadap ayam petelur periode awal pertumbuhan. Respon pertumbuhan penting diperhatikan untuk mengetahui kondisi ayam petelur dalam mempersiapkan diri sebelum mengalami masa produksi. Periode awal pertumbuhan merupakan waktu saat organ dan alat kelamin berkembang secara pesat sehingga dengan mengukur berat bagian tubuh, jaringan, dan organ akan diketahui pertumbuhan dan perkembangan yang dialami. Pertumbuhan dinyatakan dengan pengukuran kenaikan berat badan melalui penimbangan berulang-ulang yang diartikan sebagai pertumbuhan berat badan setiap hari, setiap minggu, atau waktu lainnya (Kurtini, dkk., 2011). Penelitian ini dirancang untuk menyelidiki bagaimana aflatoksin dengan kadar 9,58 ppb mempengaruhi pertumbuhan ayam petelur pada masa kritis melalui pengaplikasian pakan yang terkontaminasi oleh toksin tersebut.

\section{METODE}

\section{Bahan dan materi penelitian}

Hewan coba yang digunakan pada penelitian ini adalah 36 ekor ayam petelur DOC ayam petelur strain Isa Brown. Pakan yang digunakan pada penelitian ini yaitu pakan basal dan pakan aflatoksin (PA).

Pakan aflatoksin ditera kadar dan kandungan aflatoksin B1, B2, G1, dan G2 pada laboratorium uji dan didapatkan hasil 9,58 ppb. Kandang hewan coba yang digunakan berupa kandang brooder untuk pemeliharaan DOC selama satu minggu dilanjutkan 
dengan sejumlah 36 kandang baterai masing-masing berukuran $30 \times 40 \mathrm{~cm}$. Kandang dilengkapi tempat pakan dan minum. Peralatan pendukung lainnya seperti koran plastic, trasbag, sabun cuci tangan, sapu, glove, masker, jas laboratorium, termometer, timbangan Ohaus, dan timbangan analitik digital.

\section{Perlakuan}

Tahap pertama ayam petelur DOC dipelihara dalam kandang indukan hingga berumur satu minggu diberi pakan starter ayam petelur CP 521 yang berkadar protein 19-21\% sebanyak 1,1 gram/ekor. Selama satu minggu ini ayam diadaptasikan dalam satu kandang brooder. Berikutnya ayam dibagi secara acak ke kandang baterai dengan tetap diberikan pakan CP 521 hingga berumur 20 hari. Selama tahapan tersebut, ayam divaksinasi ND pada hari pertama, dan hari ke-14. Vaksinasi IBD untuk mencegah gumburo diberikan pada hari ke-18. Vaksinasi diaplikasikan melalui tetes mulut. Selama itu ayam tetap dipantau dan dijaga suhu ruanganya antara $29^{\circ} \mathrm{C}$ sampai 31 'C. Diberikan air minum secara ad libitum dengan campuran multivitamin. Tahapan kedua setelah ayam berumur 21 hari, vaksinasi ND dilakukan lagi pada umur 35 hari. Pada tahap kedua ini pemberian pakan dilakukan sesuai dengan percobaan yang akan diamati. Pembagiannya adalah kelompok P0 sebanyak 18 ekor ayam diberikan $100 \%$ pakan komersial ayam petelur untuk grower CP 524 dan kelompok P1 sebanyak 18 ekor ayam diberikan $80 \%$ pakan komersial ayam petelur untuk grower CP 524 dengan $20 \%$ pakan aflatoksin (PA).

\section{Penimbangan berat badan}

Pada masa adaptasi penimbangan ayam petelur dilakukan beberapa kali yakni saat DOC dan saat sebelum ayam diacak masuk kandang baterai masingmasing. Setelah ayam masuk kandang baterai, ayam ditimbang sesuai dengan subkelompok umur ayam hingga hari ke-20, 40, dan 60 menggunakan timbangan Ohaous. Data pertambahan berat badan (PBB) dengan mengukur selisih berat badan awal dengan berat badan akhir setiap interval penimbangan, pada penelitian ini interval penimbangan berat badan dilakukan pada umur ayam hari ke- 20, 40, dan 60. Satuan yang digunakan adalah gram/ekor/hari. Perhitungan pertambahan berat badan adalah sebagai berikut :

PBB (g/ekor/hari) = BB Akhir- BB Awal

\section{Pembedahan ayam}

Pembedahan ayam dilakukan sesuai dengan subkelompok umur ayam hari ke-20, 40, dan 60. Data biometrik saluran pencernaan meliputi berat oesophagus, berat proventriculus, berat ventriculus, berat dan panjang duodenum, berat dan panjang jejunum, berat dan panjang ileum, serta berat dan panjang caecum ayam diukur dengan menggunakan timbangan digital analitik dan penggaris. Satuan yang digunakan adalah gram untuk berat dan centimeter untuk panjang. Berat saluran cerna yang dimaksud adalah berat relatif masing-masing bagian saluran cerna. Persentase berat relatif menurut (Christy, 2019) sebagai berikut:

Persentase berat relatif $(\%)=\frac{\text { berat organ }}{\text { berat badan }} \times 100 \%$

\section{Analisis Data}

Analisis data yang telah dikumpulkan menggunakan two-way Analysis of Variant (ANOVA) dengan interval. Jika terdapat perbedaan yang nyata selanjutnya dievaluasi menggunakan uji Duncan derajat signifikansi sebesar $5 \%(p<0,05)$. Data dianalisis secara menyeluruh dengan 
menggunakan software SPSS 20 for Windows.

HASIL DAN PEMBAHASAN Biometrik Saluran Cerna

Hasil

menggunakan analisis

menunjukkan pola hubungan

statistik faktorial antara metrik saluran cerna yang meliputi berat relatif (Tabel 1) dan panjang (Tabel 2) saluran cerna ayam petelur. duodenum, berat jejunum, berat ileum, dan berat caecum kelompok PO secara signifikan berbeda nyata $(p<0,05)$ mengalami penurunan mengikuti umur. Dimulai sejak umur 40 hari dan cenderung menurun hingga umur 60 hari, namun antara umur 40 dan 60 hari itu penurunannya tidak kelihatan perbedaan yang nyata. Pola yang sama juga ditunjukkan oleh kelompok P1 yaitu pengamatan terhadap berat oesophagus, berat proventriculus, berat

Tabel 1. Rataan dan standar deviasi (SD) persentase berat relatif saluran cerna ayam petelur umur ke-20, ke-40, dan ke-60 hari pada PO (kelompok kontrol) diberi pakan basal dan P1 (kelompok perlakuan) diberi PA.

\begin{tabular}{|c|c|c|c|c|}
\hline \multirow{2}{*}{ Variabel } & \multirow{2}{*}{ Kelompok } & \multicolumn{3}{|c|}{ Umur (hari) } \\
\hline & & 20 & 40 & 60 \\
\hline \multirow{2}{*}{$\begin{array}{c}\text { Berat } \\
\text { Oesophagus (\%) }\end{array}$} & $\mathrm{PO}$ & $0,23 \pm 0,06^{b}$ & $0,15 \pm 0,04 \mathrm{a}$ & $0,11 \pm 0,02^{a}$ \\
\hline & $\mathrm{P} 1$ & $0,41 \pm 0,14 c$ & $0,14 \pm 0,01^{a}$ & $0,10 \pm 0,02^{a}$ \\
\hline \multirow{2}{*}{$\begin{array}{c}\text { Berat } \\
\text { Proventriculus } \\
(\%)\end{array}$} & $\mathrm{PO}$ & $0,21 \pm 0,03 c$ & $0,09 \pm 0,01^{b}$ & $\begin{array}{l}0,06 \pm \\
0,01 \mathrm{ab}\end{array}$ \\
\hline & $\mathrm{P} 1$ & $0,27 \pm 0,04 d$ & $0,08 \pm 0,01^{b}$ & $0,05 \pm 0,01^{a}$ \\
\hline \multirow{2}{*}{$\begin{array}{c}\text { Berat } \\
\text { Ventriculus (\%) }\end{array}$} & $\mathrm{PO}$ & $0,97 \pm 0,18^{b}$ & $0,36 \pm 0,07 a$ & $0,28 \pm 0,04 a$ \\
\hline & $\mathrm{P} 1$ & $1,31 \pm 0,26^{c}$ & $0,36 \pm 0,06^{a}$ & $0,25 \pm 0,09 a$ \\
\hline \multirow{2}{*}{$\begin{array}{c}\text { Berat } \\
\text { Duodenum (\%) }\end{array}$} & $\mathrm{PO}$ & $0,25 \pm 0,07 b$ & $0,12 \pm 0,03^{a}$ & $0,10 \pm 0,02^{a}$ \\
\hline & $\mathrm{P} 1$ & $0,30 \pm 0,12^{b}$ & $0,12 \pm 0,03^{a}$ & $0,10 \pm 0,02^{a}$ \\
\hline \multirow{2}{*}{$\begin{array}{c}\text { Berat } \\
\text { Jejunum (\%) }\end{array}$} & $\mathrm{PO}$ & $0,58 \pm 0,11^{b}$ & $0,27 \pm 0,05^{a}$ & $0,26 \pm 0,04 a$ \\
\hline & $\mathrm{P} 1$ & $0,98 \pm 0,24 c$ & $0,30 \pm 0,06^{a}$ & $0,25 \pm 0,04 a$ \\
\hline \multirow{2}{*}{$\begin{array}{l}\text { Berat } \\
\text { Ileum }(\%)\end{array}$} & PO & $0,06 \pm 0,01^{b}$ & $0,05 \pm 0,02^{\mathrm{ab}}$ & $0,03 \pm 0,01^{a}$ \\
\hline & $\mathrm{P} 1$ & $0,13 \pm 0,02^{c}$ & $0,04 \pm 0,01^{a}$ & $0,04 \pm 0,01^{a}$ \\
\hline \multirow{2}{*}{$\begin{array}{c}\text { Berat } \\
\text { Caecum (\%) }\end{array}$} & $\mathrm{PO}$ & $0,19 \pm 0,06^{b}$ & $0,14 \pm 0,03^{\mathrm{ab}}$ & $0,11 \pm 0,02^{a}$ \\
\hline & $\mathrm{P} 1$ & $0,40 \pm 0,06^{c}$ & $0,11 \pm 0,02^{a}$ & $0,10 \pm 0,01^{a}$ \\
\hline
\end{tabular}

Keterangan: Superskrip yang berbeda di dalam baris dan kolom untuk setiap bagian saluran cerna yang sama menunjukkan perbedaan yang signifikan $(\mathrm{p}<0.05)$.

Pengamatan terhadap berat saluran cerna berdasarkan umur baik pada kelompok P0 dan P1 menunjukkan pola yang sama pada seluruh bagian saluran cerna. Berat oesophagus, berat proventriculus, berat ventriculus, berat ventriculus, berat duodenum, berat jejunum, berat ileum, dan berat caecum kelompok P1 secara signifikan berbeda nyata $(p<0,05)$ mengalami penurunan mengikuti umur. Keistemewaan terlihat pada pengamatan berat proventriculus 
kelompok P1 umur 20, 40, dan 60 hari menunjukkan perbedaan nyata terjadinya penurunan berat proventriculus dengan nilai masingmasing sebesar 0,27 gram, 0,08 gram, dan 0,05 gram. Pengamatan faktor gabungan antara hubungan kelompok dan umur menunjukkan berbeda nyata $(\mathrm{p}<0,05)$ terhadap berat oesophagus, berat proventriculus, berat ventriculus, berat jejunum, berat ileum, dan berat caecum dengan pola yang hampir sama. Terlihat bahwa selama perlakuan antar dua kelompok ditunjukkan berat tertinggi terdapat pada kelompok P1 umur 20 hari, sedangkan berat terendah terdapat pada kelompok P1 umur 60 hari.

Paparan aflatoksin pada 20 hingga 40 hari menunjukkan perubahan pada penurunan berat oesophagus, proventriculus, ventriculus, jejunum, ileum, dan caecum. Pemberian aflatoksin dosis rendah dalam waktu yang lama pada unggas muda memberikan efek penurunan pertumbuhan. Keadaan ini sesuai dengan penelitian yang dilakukan oleh Yunus, et al. (2011) bahwa pemberian aflatoksin selama 3 minggu kepada ayam mampu menunjukkan penurunan terhadap berat keseluruhan usus, tetapi panjangnya cenderung meningkat.

Yunus, et al. (2011) mengatakan bahwa saluran gastrointestinal merupakan tempat lewat pertama aflatoksin masuk ke tubuh. Aflatoksin yang berkontak langsung dengan saluran cerna diduga menyebabkan terjadinya kerusakan pada strukturnya sehingga tampak penurunan pada berat relatif saluran cerna. Kerusakan yang terjadi bisa ditunjukkan dengan rusaknya morfologi jaringan saluran cerna berupa meningkatnya kedalam kripta, menurunnya tinggi vili, dan menurunnya rasio antara kedalam kripta dan tinggi vili di bagian usus, serta menurunnya ketebalan epitel sehingga memperluas permukaan mukosa usus (Yunus, et al., 2011; Zhang, et al., 2014). Akhirnya kerusakan yang terjadi pada struktur jaringan tersebut mempengaruhi dari konsistensi kepadatan berat relatif ataupun panjang saluran cerna.

Struktur jaringan dari saluran cerna terutama usus terdiri dari lapisan epitel, lamina propria dan kelenjar, serta lapisan muskularis. Lapisan tersebut membentuk morfologi jaringan usus mulai dari mukosa (Peng, et al., 2014). Epitel mempunyai peran dalam menjaga keseimbangan jaringan usus, dimana sel-sel yang hilang pada vili usus akan diganti pada tingkat yang sama dengan proliferasi sel pada kripta. Proses ini dikendalikan oleh mekanisme apoptosis yang terutama terdapat pada bagian vili usus yang sering rusak. Aflatoksin secara langsung atau tidak langsung mempengaruhi mekanisme apoptosis saluran cerna sehingga menganggu proses proliferasi sel. Penelitian yang dilakukan Peng, et al. (2014) menunjukkan bahwa aflatoksin menyebabkan apoptosis berlebihan pada ayam broiler sehingga berdampak pada perubahan patologis dan berkurangnya proliferasi seluler jejunum. Indikasi ini menunjukkan bahwa penurunan proliferasi sel dan atau meningkatnya kematian sel akan mengurangi jumlah sel.

Kekhususan terdapat pada hubungan antara perlakuan dan umur terhadap berat duodenum tidak berbeda nyata $(p>0,05)$. Terlihat dari rata-rata berat duodenum antara dua kelompok tersebut hasilnya sama. Secara keseluruhan pengaruh pemberian aflatoksin terhadap berat duodenum menunjukkan tidak berbeda nyata meskipun mengikuti umur terlihat terjadi penurunan berat relatif duodenum. Diduga bahwa duodenum masih mampu mempertahankan efek aflatoksin melalui mekanisme sekresi enzim yang erat kaitannya dengan pankreas. Asumsi ini didasarkan atas 
penelitian yang dilakukan oleh Matur (2010) mengatakan bahwa pemberian aflatoksin kadar rendah menyebabkan terjadinya perbaikan pada enzim pencernaan pankreas diantaranya amylase, tryspin, dan chymotrypsin. Kadar enzim amylase, trypsin, dan chymotrypsin pada pankreas mengalami peningkatan. Penelitian lainnya menyebutkan peningkatan pada enzim pencernaan terjadi karena akibat dari efek patologis aflatoksin di jaringan atau mungkin menjadi respon kompensasi untuk mengurangi asupan pakan dan defisiensi nutrisi selama saluran cerna terpapar aflatoksin.

Sebelumnya Applegate, et al. (2009) melaporkan bahwa mekanisme kompensasi serupa nitrogen, bahan kering, dan pemanfaatan energi terkait dengan menurunnya asupan nutrisi pakan ayam petelur. Namun, aflatoksin tetaplah memberikan pengaruh negatif terhadap fungsi saluran cerna ayam petelur. Adanya efek aflatoksin terhadap perbaikan aktivitas enzim pencernaan perlu diperhatikan faktor lain yang mempengaruhinya seperti dosis aflatoksin yang digunakan, jenis hewan, dan lama paparan (Matur, 2010).
Tabel

2.

menunjukkan pengamatan terhadap panjang saluran cerna berdasarkan umur baik pada kelompok P0 maupun P1 menunjukkan pola yang sama. Panjang oesophagus, duodenum, jejunum, dan ileum secara signifikan berbeda nyata $(p<0,05)$ mengalami penambahan panjang mengikuti umur. Pertambahan panjang saluran cerna terlihat berbeda signifikan mulai pada umur 20 hari sampai dengan umur 60 hari. Pengamatan faktor gabungan antara hubungan kelompok dan umur menunjukkan tidak berbeda nyata $(\mathrm{p}>0,05)$ terhadap panjang oesophagus, duodenum, dan jejunum. Sedangkan, terhadap panjang ileum terdapat perbedaan nyata $(\mathrm{p}<0,05)$ dengan nilai signifikansi sebesar 0,001.

Pemberian pakan mengandung aflatoksin diduga tidak menyebabkan terjadinya gangguan terhadap panjang saluran cerna karena sesuai dengan penelitian yang dilakukan oleh Yunus (2011) mengatakan bahwa terjadinya peningkatan panjang duodenum dan jejunum pada ayam yang diberikan paparan aflatoksin kadar tinggi merupakan upaya untuk kompensasi.

Tabel 2. Rerata dan standar deviasi (SD) panjang saluran cerna ayam petelur umur ke-20, ke-40, dan ke-60 hari pada P0 (kelompok kontrol) diberi pakan basal dan P1 (kelompok perlakuan) diberi PA.

\begin{tabular}{ccccc}
\hline Panjang & Kelompok & \multicolumn{3}{c}{ Umur (hari) } \\
\cline { 2 - 5 } & 20 & $\mathbf{4 0}$ & $\mathbf{6 0}$ \\
\hline $\begin{array}{c}\text { Oesophagus } \\
\text { (cm) }\end{array}$ & P0 & $8,55 \pm 0,60^{\mathrm{a}}$ & $9,82 \pm 0,97^{\mathrm{ab}}$ & $10,92 \pm 1,59^{\mathrm{bc}}$ \\
& $\mathrm{P} 1$ & $8,57 \pm 0,60^{\mathrm{a}}$ & $9,82 \pm 0,97^{\mathrm{ab}}$ & $11,45 \pm 1,48^{\mathrm{c}}$ \\
Duodenum & $\mathrm{P} 0$ & $15,02 \pm 1,53^{\mathrm{a}}$ & $17,70 \pm 1,27^{\mathrm{b}}$ & $21,73 \pm 1,75^{\mathrm{c}}$ \\
(cm) & $\mathrm{P} 1$ & $17,17 \pm 1,33^{\mathrm{b}}$ & $18,37 \pm 0,73^{\mathrm{b}}$ & $21,00 \pm 1,76^{\mathrm{c}}$ \\
Jejunum & $\mathrm{P} 0$ & $51,58 \pm 4,90^{\mathrm{a}}$ & $62,27 \pm 8,69^{\mathrm{b}}$ & $83,30 \pm 9,38^{\mathrm{c}}$ \\
(cm) & $\mathrm{P} 1$ & $60,67 \pm 9,03^{\mathrm{ab}}$ & $67,23 \pm 9,20^{\mathrm{b}}$ & $78,20 \pm 5,13^{\mathrm{c}}$ \\
& $\mathrm{P} 0$ & $7,78 \pm 0,71^{\mathrm{a}}$ & $12,25 \pm 1,95^{\mathrm{bc}}$ & $11,72 \pm 1,11^{\mathrm{b}}$ \\
Ileum (cm) & $\mathrm{P} 1$ & $11,48 \pm 1,37^{\mathrm{b}}$ & $10,98 \pm 1,44^{\mathrm{b}}$ & $13,45 \pm 1,47^{\mathrm{c}}$ \\
\hline
\end{tabular}

Keterangan: Superskrip yang berbeda di dalam baris dan kolom untuk setiap bagian saluran cerna yang sama menunjukkan perbedaan yang signifikan $(p<0.05)$. 
Namun, dalam penelitian ini aflatoksin dengan kadar rendah diduga belum memberikan efek pada peningkatan panjang oesophagus, duodenum, jejunum, dan ileum. Diasumsikan bahwa peningkatan panjang saluran cerna tersebut terjadi sesuai dengan keadaan normal pertumbuhan tubuh.

Jejas kerusakan yang ditimbulkan aflatoksin membuat homeostasis saluran cerna terganggu sehingga tidak hanya ikut mempengaruhi struktur jaringan saluran cerna, namun juga menganggu fungsi dari saluran cerna tersebut dalam menyerap makanan. Namun hingga saat ini belum dapat dipastikan dengan jelas seberapa banyak kontribusi aflatoksin dalam mengurangi penyerapan nutrisi yang terjadi yang berdampak terhadap pertumbuhan dan efesiensi pakan unggas. Peningkatan nutrisi pakan diperlukan untuk mengkompensasi proses penyerapan yang terganggu (Monson, et al., 2015).

\section{Pertambahan Berat Badan}

Pengamatan terhadap pertambahan berat badan ayam petelur baik kelompok kontrol (P0) maupun kelompok perlakuan (P1) menunjukkan pola yang sama. Pertambahan berat badan PO secara signifikan $(\mathrm{p}<0,05)$ meningkat mengikuti umur.
Demikian juga dengan pertambahan berat badan $\mathrm{P} 1$ secara signifikan $\quad(p<0,05) \quad$ meningkat mengikuti umur. Pengamatan berdasarkan faktor kelompok antara PO dan P1 pada masing-masing umur ayam 20, 40, dan 60 hari menunjukkan tidak berbeda nyata $(p>0,05)$. Kemudian pengamatan faktor gabungan berdasarkan hubungan antar kelompok dan umur juga menunjukkan tidak berbeda nyata $(p>0,05)$ dengan nilai signifikansinya sebesar 0,680. Hasil analisis statistic hubungan antara kelompok dan umur terhadap pertambahan berat badan (Tabel 3).

Pemberian aflatoksin tidak memberikan pengaruh terhadap pertambahan berat badan. Penyebabnya diduga karena dosis aflatoksin sebesar 9,58 ppb dalam 20\% pakan aflatoksin (PA) yang diberikan belum mempengaruhi secara signifikan dalam menurunkan pertambahan berat badan.

Tabel 3. Rataan dan standar deviasi (SD) pertambahan berat badan ayam petelur umur ke-20, 40, dan 60 hari pada P0 (kelompok kontrol) diberi pakan basal dan P1 (kelompok perlakuan) diberi PA.

\begin{tabular}{cccc}
\hline \multirow{2}{*}{ Umur } & \multicolumn{3}{c}{ Pertambahan Berat Badan (gr) } \\
\cline { 2 - 4 } KelompoK & 20 & 40 & 60 \\
\hline P0 & $76,05 \pm 6,95^{\mathrm{a}}$ & $280,80 \pm 30,98^{\mathrm{b}}$ & $571,05 \pm 69,21^{\mathrm{c}}$ \\
P1 & $75,37 \pm 7,03^{\mathrm{a}}$ & $302,20 \pm 41,52^{\mathrm{b}}$ & $564,05 \pm 51,75^{\mathrm{c}}$ \\
\hline
\end{tabular}

Keterangan: Superskrip yang berbeda di dalam baris dan kolom yang sama menunjukkan perbedaan yang signifikan $(\mathrm{p}<0.05)$. 


\section{Tidak} antarkelompok ada perbedaan pertambaha penelitian ini sesuai dengan penelitian Ahangaran dan Noosha (2011) aflatoksin pada ayam broiler selama 4 minggu tidak memberikan efek yang signifikan antara kelompok perlakuan dan kontrol. Bahkan pada penelitian sebelumnya oleh Kermanshahi, et al. (2007) pemberian pakan yang mengandung aflatoksin sebesar 1,2 $\mathrm{mg} / \mathrm{kgBB}$ selama umur 0-42 hari tidak memberikan perubahan signifikan pada berat badan ayam broiler. Beberapa faktor yang dapat mempengaruhi pertambahan berat badan hewan yang diberikan aflatoksin adalah umur, dosis, dan lama paparan. Pemberian aflatoksin dalam dosis rendah akan tetap meningkatkan berat badan, sedangkan pemberian dalam dosis tinggi akan menurunkan pertambahan berat badan. Aflatoksin dalam dosis rendah tidak memberikan efek pada berat badan karena tubuh masih mampu mempertahankan keseimbangan dan mengikuti pola hormesis (Diaz, et al., 2008).

Efek paparan aflatoksin tidak tampak menunjukkan dampak ataupun gejala kepada tubuh. Hal ini karena efek aflatoksin terutama terjadi pada hepar disebabkan hepar merupakan organ penetralisir zat toksik dalam tubuh dan menjadi target organ yang diserang aflatoksin (Peng, et al., 2016). Tidak adanya perbedaan pada pertambahan berat badan kelompok kontrol dan perlakuan menunjukkan bahwa hepar masih mampu menetralisir sebagian zat toksik dari aflatoksin sebelum diedarkan oleh pembuluh darah ke bagian tubuh yang lain. Efek paparan aflatoksin ditunjukkan dengan mengubah secara langsung atau tidak terhadap berat tubuh secara alamiah. Unggas muda sangat sensitif terhadap kontaminasi aflatoksin dan mampu bereaksi terhadap dosis rendah dalam kisaran 15-30 ppb (Rawal, et al., 2010). Selain itu, tidak ada perbedaan pada pemberian aflatoksin pada pertambahan berat badan ayam petelur umur 20-60 hari diduga karena adanya karakteristik tersendiri yang dimiliki oleh unggas ini pada umur tersebut dalam mengkompensasi zat toksik yang masuk.

\section{KESIMPULAN}

Berdasarkan penelitian dan pembahasan hasil didapatkan kesimpulan bahwa pemberian pakan mengandung aflatoksin sebesar 9,58 ppb memberikan pengaruh terhadap biometrik beberapa saluran cerna meliputi penurunan berat oesophagus, berat proventrikulus, berat ventrikulus, berat jejunum, berat ileum, berat caecum, dan pertambahan panjang ileum. Serta pemberian pakan mengandung aflatoksin sebesar 9,58 ppb tidak memberikan pengaruh pada pertambahan berat badan ayam petelur periode awal pertumbuhan.

\section{DAFTAR PUSTAKA}

Ahangaran, Majid G., and Noosha ZiaJahromi. 2011. Nanosilver Effect on Growth Parameters in Experimental Aflatoxicosis in Broiler Chickens. Toxicology and Industrial Health. 29(2): 121-125.

Applegate, T.J., G. Schatzmayr, K. Pricket, C. Troche, and Z. Jiang. 2009. Effect of Aflatoksin Culture on Intestinal Function and Nutrient Loss in Laying Hens. Poultry Science. 88 : 1235-1241.

Cristy, Rachella. 2019. Pengaruh Pakan Terkontaminasi Aflatoksin terhadap Anatomi dan Histopatologi Timus Ayam Petelur Fase Starter. [Skripsi]. Fakultas Kedokteran Hewan. Universitas Airlangga. Hal. 20. 
Diaz, G. J., E. Calabrese, and R. Blain. 2008. Aflatoxicosis in chickens (Gallus gallus): An example of hormesis? Poult. Sci. 87:727-732.

Kermanshahi, H., M.R. Akbari, M. Maleki, and M. Behgar. 2007. Effect of Prolonged Low Level Inclusion of Aflatokxin $\mathrm{B}_{1}$ into Diet on Performance, Nutrient Digestibility, Histopathology, and Blood Enzymes of Broiler Chickens. Journal of Animal and Veterinary Advances. 6(5); 686-692.

Kurtini, T., K. Nova., dan D. Septinova. 2011. Produksi Ternak Unggas. Universitas Lampung, Bandar Lampung.

Liu, Y.G.K. 2002. Prevention and Control of Molds and Mycotoxins in Raw Materials and Final Feeds in Tropical Countries. In: Feed and Grain Quality Workshop. US Garin Council, American Soybean. p.1-23.

Maryam R., Y. Sani, S. Juariah, R. Firmansyah, dan Miharja. 2003. Efektifitas Ekstrak Bawang Putih (Allium sativum Linn) dalam Penanggulangan Aflatoksikosis Pada Ayam Petelur. Dalam Prosiding Seminar Nasional Teknologi Peternakan dan Veteriner 2003. Puslitbangnak. Bogor.

Matur, E., E. Ergul, I. Akyazi, E. Eraslan, and Z.T. Ciraklit. 2010. The Effect of Saccharomyces cerevisiae Extract on The Weight of Some Organs, Liver, and Pancreatic Digestive Enzyme Activity In Breeder Hens Fed Diets Contaminated With Aflatoxins. Poultry Science. 89: 22132220.

Monson, Melissa S., R.A. Coulombe, and K.M. Reed. 2015. Aflatoxicosis : Lesson from Toxicity and Responses to Aflatoxin B1 in Poultry. Agriculturale Journal. 5 : 742-777.

Puspitasari, C. F. 2018. Evaluasi Cemaran Aflatoksin pada Bahan Baku Pakan dan Pakan Ayam di Peternakan Ayam Petelur [Tesis]. Fakultas Kedokteran Hewan. Universitas Airlangga. Surabaya. Hal. 23.

Peng, Xi., Z. Yu, N. Liang, X. Chi, X. Li, M. Jiang, J. Fang, H. Cui, W. Lai, Y. Zhou, and S. Zhou. 2016. The Mitochondrial and Death Receptor Pathways Involved in the Thymocytes Apoptosis Induced by Aflatoxin $\mathrm{B}_{1}$. Oncotarget. 7(11): 12222-12234.

Peng, Xi., S. Zhang, J. Fang, H.Cui, Z. Zuo, and J. Deng. 2014. Protective Roles of Sodium Selenite Againts Aflatoxin $\mathrm{B}_{1}$-Induced Apoptosis of Jejunum in Broilers. Internasional Journal of Enviromental Research and Public Health. 11 :13130-13143.

Rawal, S., J.F. Kim and R. Coulombe. 2010. Aflatoxin B1 in Poultry: Toxicology, Metabolism and Prevention. Research in Veterinary Science. 89: 325-331.

Reddy, K.R.N., B. Salleh, B. Saad, H.K. Abbas, C.A. Abel, and W.T. Shier. 2010. An Overview of Mycotoxin Contamination in Foods and its Implications for Human Health. Toxin Rev. 29: 16-39.

Singh, R. and A.B. Mandal. 2014. Efficacy of Fumaric and Citric Acids in Preventing Biosynthesis of Aflatoxins in Poultry Feed with Variable Moisture Content. Ind. J. Ani Sci. 84(4): 453-456.

Unutio, Ericko., Hamdan, dan Tri Hesti W. 2016. Analisis Regresi Dan Korelasi Antara Seleksi Bobot Badan 
Fase Starter Terhadap Produksi Ayam Ras Petelur Tipe Medium. Jurnal Peternakan Integratif. 3(2) :190-200.

Valchev, I., V. Marutsova, I. Zarkov, A. Ganchev and Y. Nikolov. 2017. Effects of aflatoxin B1 alone or coadministered with Mycotox NG on performance and humoral immunity of turkey broilers. Bulg. J. Vet. Med. 20 (1): 38-50.

Walukow, K.S., J. Laihad, J.R. Leke, dan M. Montong. 2017. Penampilan Produksi Ayam Ras Petelur MB 402 yang Diberi Ransum Mengandung Minyak Limbah Ikan Cakalang (Katsuwonus pelamis L). Jurnal Zootek. 37(1): 123-134.

Wijayanti, D.A. 2010. Penentuan Kadar Aflatoxin Bl dalam Pakan Broiler Secara Kromatografi Cair Kinerja Tinggi dengan Pemurnian Secara
Imunoafinitas. Jurnal Sains Veteriner. 28(2): 98-103.

Yunus, A.W., K. Ghareeb, A.A. Abd-ElFattah, M. Twaruzek and J. Böhm. 2011. Gross intestinal adaptations in relation to broiler performance during chronic aflatoxin exposure. Poult. Sci. 90: 1683-1689.

Yunus, A.W., E. Razzazi-Fazeli, and J. Bohm. 2011. Aflatoxin B1 in affecting broiler's performance, immunity, and gastrointestinal tract: A review of history and contemporary issues. Toxins.3 :566-590.

Zhang, S., X. Peng, J. Fang, H. Cui, Z. Zuo, and Z. Chen. 2014. Effects of Aflatoxin B1 Exposure and Sodium Selenite Supplementation on the Histology, Cell Proliferation, and Cell Cycle of Jejunum in Broilers. Biological Trace Element Research. 160(1) : 32-40. 